\title{
Slight Increases of Phosphorus and Sulfur in Human First Septal Perforator Branches of the Left Anterior Descending Artery with
}

\section{Aging}

\section{Yoshiyuki Tohno ${ }^{1 *}$, Setsuko Tohno ${ }^{1}$, Takeshi Minami², Nutcharin Pakdeewong-Ongkana ${ }^{1}$, Noppadol Phasukdee $^{1}$ and Pasuk Mahakkanukrauh ${ }^{1,3,4}$}

\author{
${ }^{1}$ Department of Anatomy, Faculty of Medicine, Chiang Mai University, Thailand \\ ${ }^{2}$ Department of Life Science, Faculty of Science and Technology, Kinki University, Higashi-Osaka, Japan \\ ${ }^{3}$ Forensic Osteology Center, Faculty of Medicine, Chiang Mai University, Thailand \\ ${ }^{4}$ Excellence in Osteology Research and Training Center (ORTC), Chiang Mai University, Thailand
}

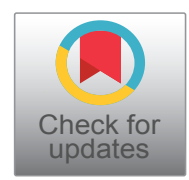

*Corresponding author: Yoshiyuki Tohno, Department of Anatomy, Faculty of Medicine, Chiang Mai University, Chiang Mai 50200, Thailand, Tel: 66-53-935312, Fax: 66-53-935304

\begin{abstract}
To elucidate age-related changes of the first septal perforator branch (FSB), the authors investigated age-related changes of elements in the FSBs by direct chemical analysis. In addition, the effects of different arterial sizes and genders on element accumulation were investigated in the FSBs. Sixty-two formalin-fixed adult Thai hearts were used and the FSBs were carefully dissected in the hearts. After the arteries were incinerated with nitric acid and perchloric acid, element contents were determined by inductively coupled plasma-atomic emission spectrometry. It was found that both the $\mathrm{P}$ and $\mathrm{S}$ contents increased significantly in the FSBs with aging, but five element contents such as $\mathrm{Ca}, \mathrm{Mg}, \mathrm{Zn}, \mathrm{Fe}$, and $\mathrm{Na}$ did not change significantly with aging. Regarding the relationships among $\mathrm{Ca}, \mathrm{P}$, and $\mathrm{Mg}$ contents, no significant direct correlations were found in the FSBs, except for an extremely significant direct correlation between $\mathrm{Ca}$ and $\mathrm{Mg}$ contents. No gender differences and effect of arterial size were found in age-related changes of $\mathrm{Ca}$ and $\mathrm{P}$ contents in the FSBs. To elucidate whether calcification occurred in the FSBs in old age, both the mass ratios of $\mathrm{Ca} / \mathrm{P}$ and $\mathrm{Mg} / \mathrm{Ca}$ were estimated in the FSBs. The mass ratio of $\mathrm{Ca} / \mathrm{P}$ increased progressively in the $\mathrm{FSBs}$ with $\mathrm{Ca}$ increase, being not constant. The mass ratio of $\mathrm{Mg} / \mathrm{Ca}$ decreased gradually in the FSBs with $\mathrm{Ca}$ increase, but the average mass ratio of $\mathrm{Mg} / \mathrm{Ca}$ was moderate, being $8.0 \pm$ $1.3 \%$. These results indicated that calcification scarcely occurred in the FSBs in old age, independently of gender and arterial size.
\end{abstract}

\section{Keywords}

First septal perforator branch, Coronary artery, Calcium, Phosphorus, Sulfur, Aging

\section{Introduction}

The conduction system of the heart is supplied by the sinoatrial nodal (SAN) artery, the atrioventricular nodal (AVN) artery, the first septal perforator branch (FSB) of the left anterior descending artery (LAD), and the posterior descending branch of the right coronary artery (RCA). These arteries ensure adequate blood supply to maintain the electrical properties in the heart. It is well known that a high accumulation of $\mathrm{Ca}$ and $\mathrm{P}$ occurs in the proximal sites of the LAD, left coronary artery (LCA), RCA, and left circumflex artery (LCX) with aging [1-3]. For example, Montenegro and Eggen [1] studied the distribution of atherosclerotic lesions along the axis of the coronary artery (topography) and the relationship of topography to concepts of pathogenesis, and reported that a higher prevalence of atherosclerotic lesions in isolated coronary arteries occurred from the first to second centimeter of both the LAD and the RCA, with a decrease in prevalence from $3 \mathrm{~cm}$ onward in the $L A D$ and from $5 \mathrm{~cm}$ onward in the RCA.

Citation: Tohno Y, Tohno S, Minami T, Pakdeewong-Ongkana N, Phasukdee N, et al. (2020) Slight Increases of Phosphorus and Sulfur in Human First Septal Perforator Branches of the Left Anterior Descending Artery with Aging. Int Arch Vasc Med 3:004. doi.org/10.23937/2690-3164/1710004 Accepted: March 10, 2020: Published: March 12, 2020

Copyright: (c) 2020 Tohno Y, et al. This is an open-access article distributed under the terms of the Creative Commons Attribution License, which permits unrestricted use, distribution, and reproduction in any medium, provided the original author and source are credited. 
There are a few reports [4-6] on calcification of the FSB. Wasilewski et al. [4] investigated calcification of the LAD including the FSB by multi-slice computed tomography and revealed that calcification was most frequently located in the LAD in proximity to the FSB origin, but it was not located in the FSB. Velican et al. [6] investigated histological changes of four arteries supplying the conduction system of the heart and reported that intimal thickening occurred significantly in the FSB, SAN artery, AVN artery, and posterior descending artery without calcification. However, age-related changes of the FSB had not yet been studied by direct chemical analysis. Therefore, the authors investigated age-related changes of the FSBs using adult Thai hearts from a viewpoint of elements. It was found that calcification scarcely occurred in the FSBs in old age.

\section{Materials and Methods}

\section{Dissection of the FSBs}

The research was carried out on 62 adult Thai hearts (of subjects between 36 and 94 years of age; average age, $70.7 \pm 14.5$ years) received from the Department of Anatomy, Faculty of Medicine, Chiang Mai University. The perivascular fatty tissue was carefully removed, where necessary, to visualize the epicardial course of the coronary arteries. The FSBs were carefully dissected in the hearts. The FSB arising from the LAD penetrated the myocardium, ran rightwards and downwards, and distributed the interventricular septum. The FSBs were resected from the hearts.

\section{Determination of elements}

The arterial samples were washed thoroughly with distilled water and were dried at $95{ }^{\circ} \mathrm{C}$ for $16 \mathrm{~h}$. After 1 $\mathrm{ml}$ concentrated nitric acid was added to the dry samples to incinerate, they were heated at $100^{\circ} \mathrm{C}$ for $2 \mathrm{~h}$. After the addition of $0.5 \mathrm{ml}$ concentrated perchloric acid, they were heated at $100^{\circ} \mathrm{C}$ for an additional $2 \mathrm{~h}$ [7]. The samples were adjusted to a volume of $10 \mathrm{ml}$ by adding ultrapure water and were filtered through filter paper (no. 7; Toyo Roshi, Osaka, Japan). Seven elements of Ca, $\mathrm{P}, \mathrm{S}, \mathrm{Mg}, \mathrm{Zn}, \mathrm{Fe}$, and $\mathrm{Na}$ were selected for measurement because of the following reasons: Both $\mathrm{Ca}$ and $\mathrm{P}$ are directly correlated with $\mathrm{Mg}$ on calcification [8]; smooth muscles containing $S$ decrease on atherosclerosis [9]; both $\mathrm{Zn} \mathrm{[10]} \mathrm{and} \mathrm{Fe} \mathrm{[11]} \mathrm{are} \mathrm{related} \mathrm{to} \mathrm{atherosclerosis;}$ and $\mathrm{Na}$ is an important cation. The resulting filtrates were analysed by inductively coupled plasma-atomic emission spectrometry (iCAP 7400 ICP-OES Duo; Thermo Fisher Scientific Japan Inc., Kanagawa, Japan). The conditions were as follows: $1.15 \mathrm{~kW}$ from the radiofrequency forward power, an auxiliary gas flow rate of 0.5 $\mathrm{l} / \mathrm{min}$, a nebulizer gas flow rate of $0.55 \mathrm{l} / \mathrm{min}$, a coolant gas flow rate of $12 \mathrm{l} / \mathrm{min}$, a purge gas flow rate of $3.2 \mathrm{l}$ $\mathrm{min}$, and an exposure time of $10 \mathrm{~s}$. Especially prepared standard solutions of $\mathrm{Ca}, \mathrm{Mg}, \mathrm{Zn}, \mathrm{Fe}$, and $\mathrm{Na}$ for atomic absorption spectrometry and phosphate and sulfate ions for ion chromatography were purchased from
Wako Pure Chem. Ind. (Osaka, Japan) and were used as standard solutions. The measurement of elements was performed at a fixed wavelength of $588.995 \mathrm{~nm}$ for $\mathrm{Na}$, $393.366 \mathrm{~nm}$ for $\mathrm{Ca}, 279.553 \mathrm{~nm}$ for $\mathrm{Mg}, 259.940 \mathrm{~nm}$ for $\mathrm{Fe}, 213.856 \mathrm{~nm}$ for $\mathrm{Zn}, 180.731 \mathrm{~nm}$ for $\mathrm{S}$, and 177.495 $\mathrm{nm}$ for $\mathrm{P}$. The amount of elements was expressed on a dry weight basis.

\section{Statistical analysis}

Statistical analyses were performed using the GraphPad Prism version 8.0 (GraphPad Software, San Diego, CA, USA). Peason's correlation was used to investigate the association between parameters. It was analysed whether significant differences were found between two slopes and between two intercepts of the regression lines. A $p$ value of less than 0.05 was considered to be significant. Data were expressed as the mean \pm standard deviation.

\section{Results}

Table 1 indicates ages, sexes, and causes of deaths of the 62 subjects used in the present study. There were eight cases of coronary artery disease in the subjects

Table 1: Subjects used in the present study.

\begin{tabular}{|c|c|c|}
\hline Age (Years) & Sex & Cause of death \\
\hline 36 & $M$ & Epilepsy \\
\hline 36 & W & Lymphoma \\
\hline 38 & M & Strangulation \\
\hline 40 & M & Hepatic cancer \\
\hline 47 & M & Pneumonia \\
\hline 50 & W & Hepatic cancer \\
\hline 51 & M & Leukemia \\
\hline 52 & $M$ & Gunshot wound \\
\hline 53 & W & Chronic renal failure \\
\hline 55 & $M$ & Intracerebral hemorrhage \\
\hline 57 & M & Alcoholism \\
\hline 57 & M & Hypertension \\
\hline 57 & W & Cerebrovascular disease \\
\hline 57 & W & Lung cancer \\
\hline 60 & M & Urinary tract infection \\
\hline 63 & $M$ & Bile duct cancer \\
\hline 63 & W & Intracerebral hemorrhage \\
\hline 64 & M & Myocardial infarction \\
\hline 65 & M & Acute natural illness \\
\hline 66 & M & Intracerebral hemorrhage \\
\hline 66 & M & Liver cirrhosis \\
\hline 67 & $M$ & Senility \\
\hline 67 & M & Rectal cancer \\
\hline 67 & W & Heart failure \\
\hline 69 & W & Intracerebral hemorrhage \\
\hline 70 & M & Traumatic head injury \\
\hline 72 & M & Acute myocardial infarction \\
\hline
\end{tabular}




\begin{tabular}{|c|c|c|}
\hline 72 & W & Aspiration pneumonia \\
\hline 73 & M & Cardiac hypertrophy \\
\hline 73 & M & Pneumonia \\
\hline 73 & M & Septicemia \\
\hline 75 & M & Senility \\
\hline 75 & W & Senility \\
\hline 76 & W & Pneumonia \\
\hline 76 & W & Cerebrovascular disease \\
\hline 78 & M & Hepatic cancer \\
\hline 78 & M & Intracerebral hemorrhage \\
\hline 78 & M & Hyperglycemic crisis \\
\hline 78 & M & Tracheal obstruction \\
\hline 78 & W & Senility \\
\hline 78 & W & Septicemia \\
\hline 79 & M & Pneumonia \\
\hline 79 & W & Intestinal cancer \\
\hline 79 & M & Senility \\
\hline 80 & W & Senility \\
\hline 80 & W & Cardiac arrest \\
\hline 81 & M & Senility \\
\hline 81 & W & Senility \\
\hline 83 & M & Septicemia \\
\hline 83 & W & Cerebrovascular disease \\
\hline 83 & W & Infected emphysema \\
\hline 83 & M & Septicemia \\
\hline 84 & W & Senility \\
\hline 85 & M & Septicemia \\
\hline 86 & W & Pneumonia \\
\hline 87 & W & Heart failure \\
\hline 88 & M & Respiratory tract infection \\
\hline 88 & W & Myocardial infarction \\
\hline 89 & M & Pneumonia \\
\hline 92 & M & Heart failure \\
\hline 93 & W & COPD and pneumonia \\
\hline 94 & W & Pneumonia \\
\hline
\end{tabular}

Note: $\mathrm{M}$ and $\mathrm{W}$ indicate man and woman

used in the present study. The incidence of the subjects with coronary artery disease was $12.9 \%$ (8/62 cases).

\section{Age-Related Changes of Elements in the FSBS}

Figure 1 shows age-related changes of seven element contents in the 62 FSBs studied. The correlation coefficients between age and element contents were estimated to be $-0.243(p=0.057)$ for $\mathrm{Ca}, 0.296(p=$ $0.019)$ for $P, 0.308(p=0.015)$ for $S,-0.157(p=0.225)$ for $\mathrm{Mg},-0.233(p=0.069)$ for $\mathrm{Zn}, 0.213(p=0.100)$ for $\mathrm{Fe}$, and $-0.109(p=0.398)$ for Na. Significant direct correlations were found between age and either $\mathrm{P}$ or $\mathrm{S}$ content in the FSBs, but no significant correlations were found between age and the other element contents such as $\mathrm{Ca}, \mathrm{Mg}, \mathrm{Zn}, \mathrm{Fe}$, and $\mathrm{Na}$. However, both the $\mathrm{Ca}$ and $\mathrm{Zn}$ contents tended to decrease with aging.
Table 2: Incidence of an artery with the Ca content more than $5 \mathrm{mg} / \mathrm{g}$.

\begin{tabular}{|l|l|}
\hline Age group (years) & Incidence (\%) \\
\hline$<\mathbf{5 0}$ & $100 \%(5 / 5)$ \\
\hline $\mathbf{5 0 s}$ & $33.3 \%(3 / 9)$ \\
\hline $\mathbf{6 0 s}$ & $18.2 \%(2 / 11)$ \\
\hline $\mathbf{7 0 s}$ & $26.3 \%(5 / 19)$ \\
\hline $\mathbf{8 0 s}$ & $46.7 \%(7 / 15)$ \\
\hline $\mathbf{9 0 s}$ & $33.3 \%(1 / 3)$ \\
\hline
\end{tabular}

The average contents of seven elements were 5.029 $\pm 1.571 \mathrm{mg} / \mathrm{g}$ for $\mathrm{Ca}, 0.841 \pm 0.272 \mathrm{mg} / \mathrm{g}$ for $\mathrm{P}, 3.530 \pm$ $0.471 \mathrm{mg} / \mathrm{g}$ for $\mathrm{S}, 384.0 \pm 56.09 \mu \mathrm{g} / \mathrm{g}$ for $\mathrm{Mg}, 141.4 \pm$ $125.1 \mu \mathrm{g} / \mathrm{g}$ for $\mathrm{Zn}, 675.6 \pm 379.6 \mu \mathrm{g} / \mathrm{g}$ for $\mathrm{Fe}$, and 131.4 $\pm 92.65 \mu \mathrm{g} / \mathrm{g}$ for $\mathrm{Na}$. The average content was highest in $\mathrm{Ca}$, and it decreased in the order of $\mathrm{S}, \mathrm{P}, \mathrm{Fe}, \mathrm{Mg}, \mathrm{Zn}$, and $\mathrm{Na}$.

Table 2 indicates the incidence of the FSB with the $\mathrm{Ca}$ content more than $5 \mathrm{mg} / \mathrm{g}$, which is not contained in a normal artery [12]. The incidence of such an artery was $100 \%$ in both the 30 s and the 40 s of the subjects, and it ranged from $18.2 \%$ to $46.7 \%$ between the 50 s and the 90 s of the subjects. The incidence of the FSB with such a Ca content did not increase with aging. The mean incidence was $37.1 \%$ in all the FSBs studied.

\section{Relationships among Seven Element Contents in the FSBs}

The relationships among seven element contents were examined in the FSBs studied. Table 3 lists the relationships among seven element contents in the FSBs. Extremely significant direct correlations were found both between $\mathrm{Ca}$ and $\mathrm{Mg}$ contents and between $\mathrm{S}$ and $\mathrm{Mg}$ contents, and very significant direct correlations were found between $\mathrm{Ca}$ and either $\mathrm{Zn}$ or $\mathrm{Na}$ contents and between $\mathrm{Mg}$ and $\mathrm{Na}$ contents. However, no significant correlations were found between $\mathrm{Ca}$ and $\mathrm{P}$ contents and between $\mathrm{P}$ and $\mathrm{Mg}$ contents. Therefore, no significant direct correlations were found among $\mathrm{Ca}, \mathrm{P}$, and $\mathrm{Mg}$ contents in the FSBs, except for an extremely significant direct correlation between $\mathrm{Ca}$ and $\mathrm{Mg}$ contents.

\section{Gender Differences in the $\mathrm{Ca}$ and P Contents of the FSBs}

The used subjects consisted of 36 men and 26 women. The average age of men's subjects was $68.3 \pm 14.5$ years, whereas it of women's subjects was $74.0 \pm 14.1$ years. Figure 2 shows age-related changes of $\mathrm{Ca}$ and $\mathrm{P}$ contents in men and women's FSBs. The correlation coefficients between age and Ca content (Figure 2a) were estimated to be $-0.156(p=0.363)$ in men's FSBs and $-0.438(p=0.025)$ in women's FSBs. A significant inverse correlation was found between age and Ca content in women's FSBs, but no significant correlation was found in men's FSBs. The correlation coefficients between age 

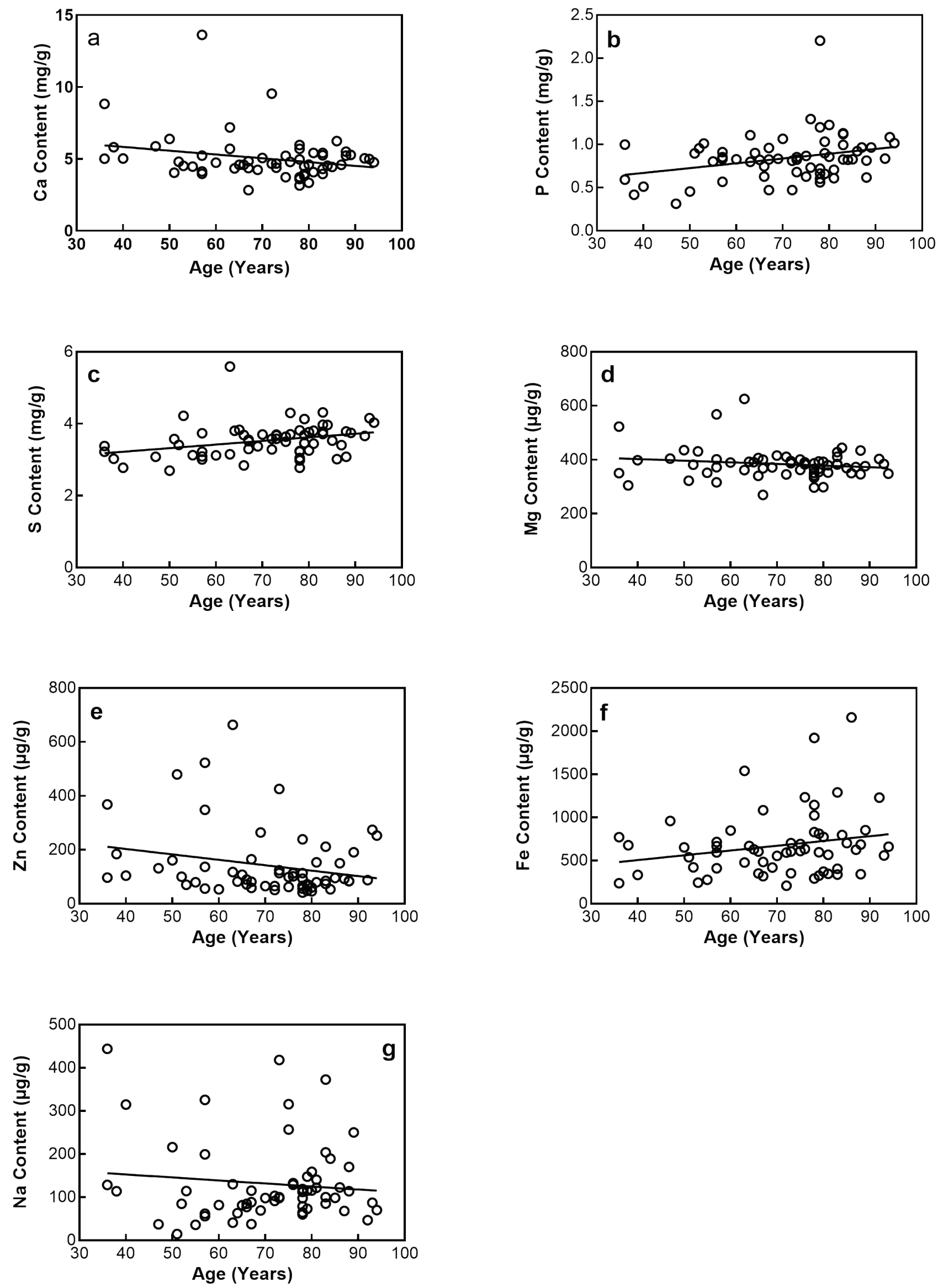

Figure 1: Age-related changes of $\mathrm{Ca}(\mathrm{a}), \mathrm{P}(\mathrm{b}), \mathrm{S}(\mathrm{c}), \mathrm{Mg}(\mathrm{d}), \mathrm{Zn}(\mathrm{e}), \mathrm{Fe}(\mathrm{f})$, and $\mathrm{Na}(\mathrm{g})$ contents in the FSBs. 
Table 3: Relationships among seven element contents in the FSBs.

\begin{tabular}{|l|l|l|l|l|l|l|}
\hline \multirow{2}{*}{ Element } & \multicolumn{2}{|l}{ Correlation coefficient and $\boldsymbol{p}$ value } & \multicolumn{3}{l|}{} & \\
\cline { 2 - 7 } & $\mathrm{P}$ & $\mathrm{S}$ & $\mathrm{Mg}$ & $\mathrm{Zn}$ & $\mathrm{Fe}$ & $\mathrm{Na}$ \\
\hline $\mathbf{C a}$ & $-0.193(0.133)$ & $-0.078(0.549)$ & $0.616(<0.0001)$ & $0.379(0.002)$ & $0.056(0.669)$ & $0.338(0.007)$ \\
\hline $\mathbf{P}$ & & $0.240(0.060)$ & $0.028(0.827)$ & $-0.106(0.411)$ & $-0.101(0.441)$ & $-0.085(0.510)$ \\
\hline $\mathbf{S}$ & & & $0.434(0.0004)$ & $-0.036(0.782)$ & $-0.111(0.394)$ & $-0.039(0.766)$ \\
\hline $\mathbf{M g}$ & & & & $0.157(0.224)$ & $-0.008(0.952)$ & $0.341(0.007)$ \\
\hline Zn & & & & $0.057(0.659)$ & $0.220(0.086)$ \\
\hline Fe & & & & & & $-0.051(0.693)$ \\
\hline
\end{tabular}

$p$ Values are indicated in parentheses
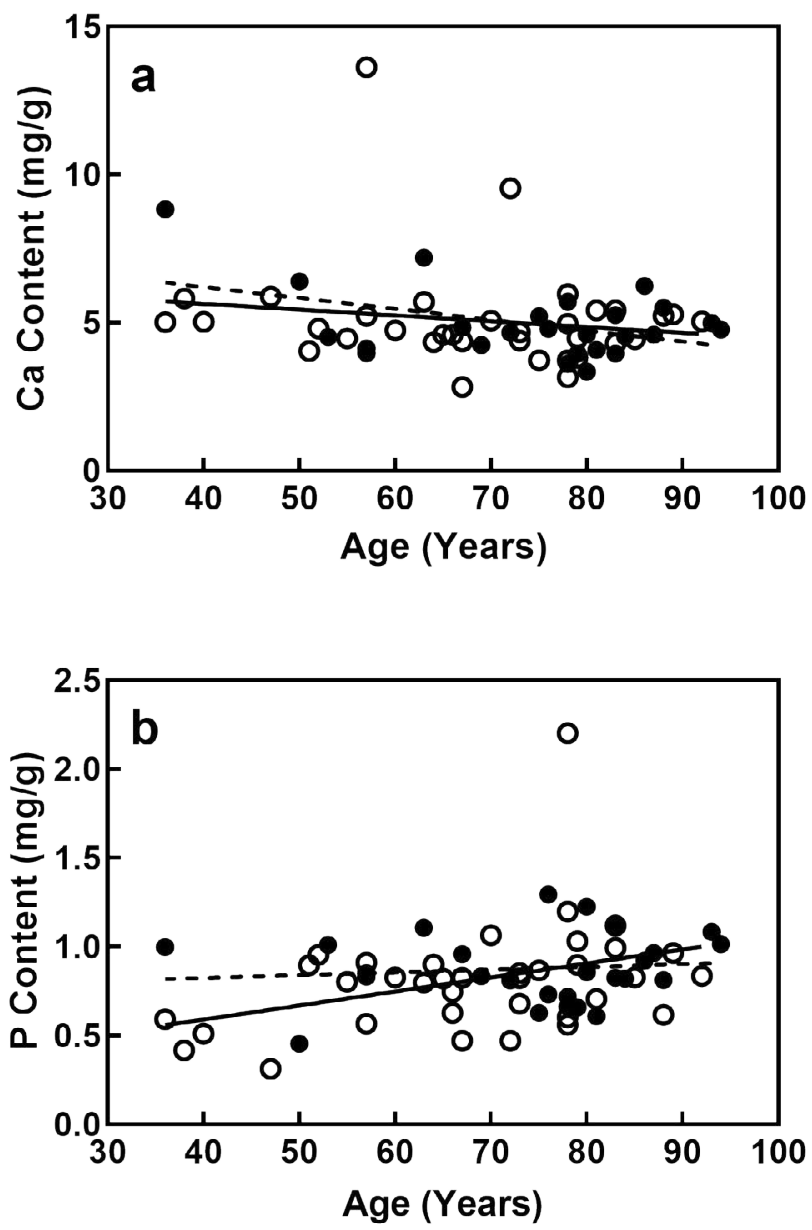

Figure 2: Age-related changes of $\mathrm{Ca}(\mathrm{a})$ and $\mathrm{P}(\mathrm{b})$ contents in men and women's FSBs. The open and solid circles indicate men and women's FSBs. The straight and dotted lines of trend with age indicate men and women's FSBs, respectively.

relation was found in women's FSBs. Therefore, the Ca content decreased significantly and gradually in women's FSBs with aging, whereas the $P$ content increased significantly and progressively in men's FSBs with aging.

The analysis of the regression lines between age and Ca content in Figure 2a showed that no significant differences were found between the two slopes $(p=0.550)$ and between the two intercepts $(p=0.962)$ of the regression lines for men and women's FSBs. The analysis of the regression lines between age and $P$ content in Figure $2 b$ showed that no significant differences were
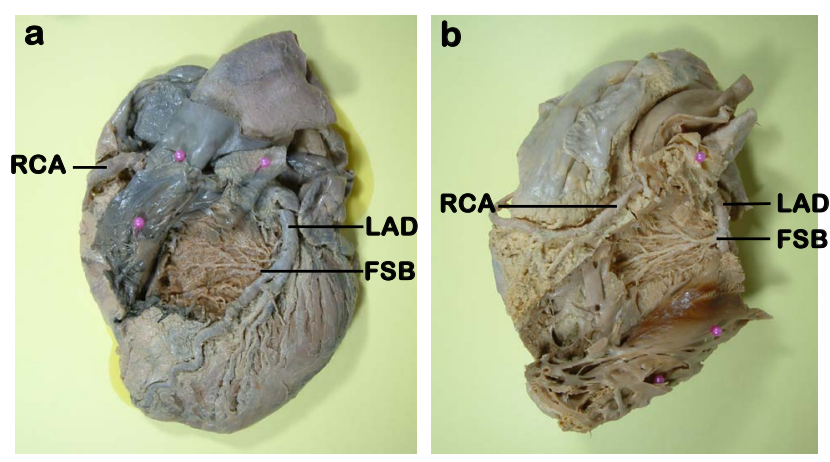

Figure 3: Anterior views of smaller (a) and larger (b) FSBs. FSB, first septal perforator branch; LAD: left anterior descending artery; RCA: right coronary artery.

found between the two slopes $(p=0.192)$ and between the two intercepts $(p=0.634)$ of the regression lines for men and women's FSBs. Therefore, no gender differences were found in the FSBs with regard to age-related changes of $\mathrm{Ca}$ and $\mathrm{P}$ contents.

\section{Effect of Arterial Size on Age-Related Changes of $\mathrm{Ca}$ and $\mathrm{P}$ Contents}

To examine an effect of arterial size on age-related changes of elements, the FSBs were separated into the smaller group $(n=40)$ less than $1.40 \mathrm{~mm}$ of the outer diameter and the larger group $(n=22)$ more than 1.40 $\mathrm{mm}$ of the outer diameter (Figure 3). The smaller group ranged in age from 36 to 94 years (average age, 70.4 \pm 14.9 years), whereas the larger group ranged in age from 36 to 88 years (average age, $71.2 \pm 14.0$ years). The two groups were separately analysed to examine whether age-related changes of $\mathrm{Ca}$ and $\mathrm{P}$ contents were different between smaller and larger groups.

Figure 4 shows age-related changes of $\mathrm{Ca}$ and $\mathrm{P}$ contents in both the smaller and larger groups. The correlation coefficients between age and Ca content (Figure 4a) were estimated to be $-0.310(p=0.052)$ in the smaller group and $-0.081(p=0.719)$ in the larger group. No significant correlations were found between age and $\mathrm{Ca}$ content in two groups. The correlation coefficients between age and $\mathrm{P}$ content (Figure $4 \mathrm{~b}$ ) were estimated to be $0.307(p=0.054)$ in the smaller group and 0.304 ( $p$ $=0.169$ ) in the larger group. No significant correlations were found between age and $\mathrm{P}$ content in two groups.

The analysis of the regression lines between age 

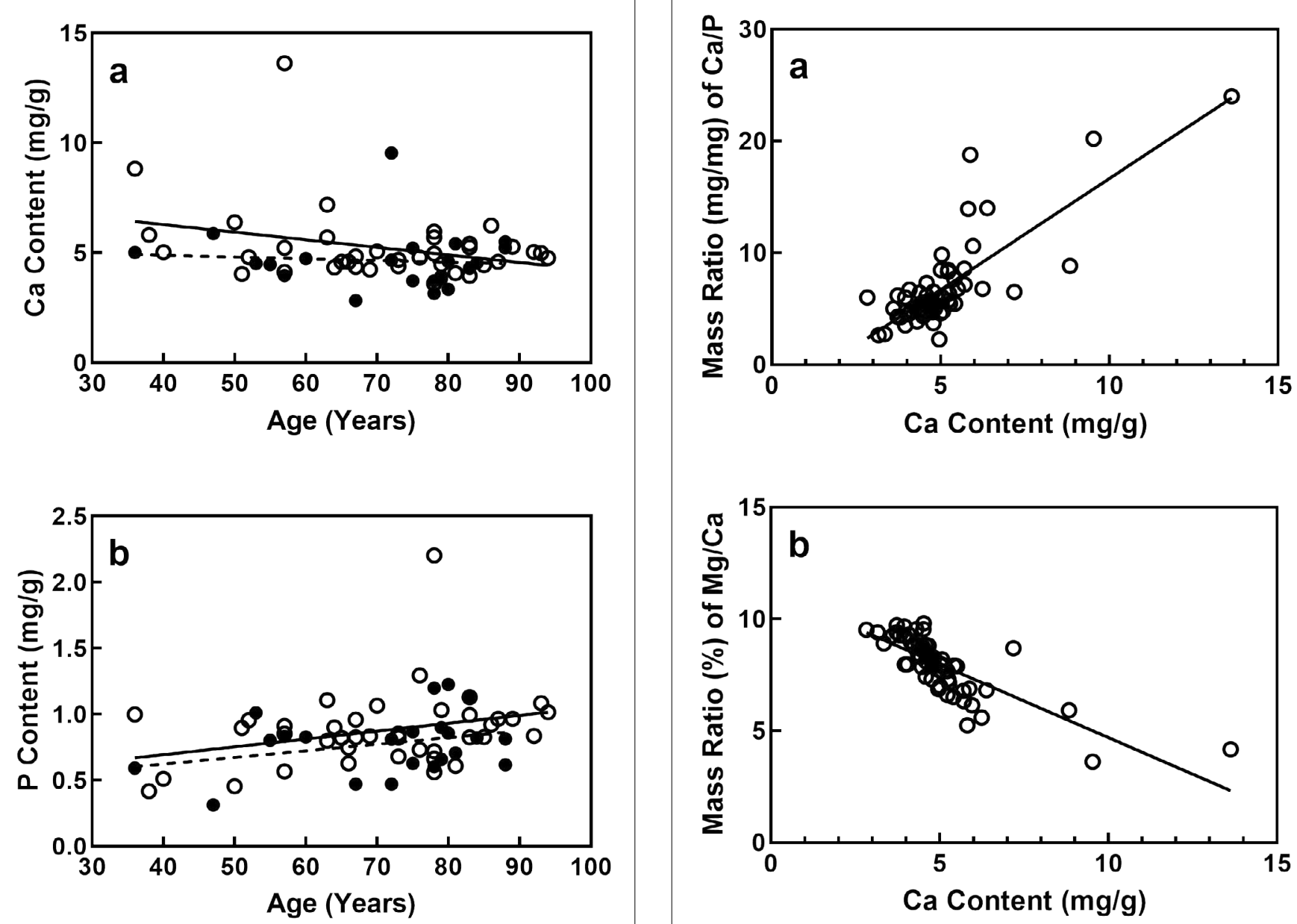

Figure 4: Age-related changes of $\mathrm{Ca}(\mathrm{a})$ and $\mathrm{P}(\mathrm{b})$ contents in the smaller group less than $1.4 \mathrm{~mm}$ of the outer diameter and the larger group more than $1.4 \mathrm{~mm}$ of the outer diameter in the FSBs. The open and solid circles indicate smaller and larger groups. The straight and dotted lines of trend with age indicate smaller and larger groups.

and $\mathrm{Ca}$ content in Figure $4 \mathrm{a}$ showed that no significant differences were found between the two slopes ( $p=$ $0.360)$ and between the two intercepts $(p=0.162)$ of the regression lines for the smaller and larger groups. The analysis of the regression lines between age and $P$ content in Figure $4 \mathrm{~b}$ showed that no significant differences were found between the two slopes $(p=0.850)$ and between the two intercepts $(p=0.152)$ of the regression lines for the smaller and larger groups. Therefore, no significant differences were found in age-related changes of $\mathrm{Ca}$ and $\mathrm{P}$ contents between the smaller and larger groups.

\section{Mass Ratios of $\mathrm{Ca} / \mathrm{P}$ and $\mathrm{Mg} / \mathrm{Ca}$ in the FSBs}

To elucidate whether calcification occurred in the FSBs in old age, both the mass ratios of $\mathrm{Ca} / \mathrm{P}$ and $\mathrm{Mg} /$ Ca were investigated in the $62 \mathrm{FSBs}$ studied. Figure 5 shows changes of both the mass ratios of $\mathrm{Ca} / \mathrm{P}$ and $\mathrm{Mg} /$ $\mathrm{Ca}$ in the FSBs as a function of Ca content. The correlation coefficient was estimated to be $0.796(p<0.0001)$ between the mass ratio of $\mathrm{Ca} / \mathrm{P}$ and $\mathrm{Ca}$ content Figure $5 a$. The mass ratio of $\mathrm{Ca} / \mathrm{P}$ increased significantly and progressively with $\mathrm{Ca}$ increase, being not constant. The

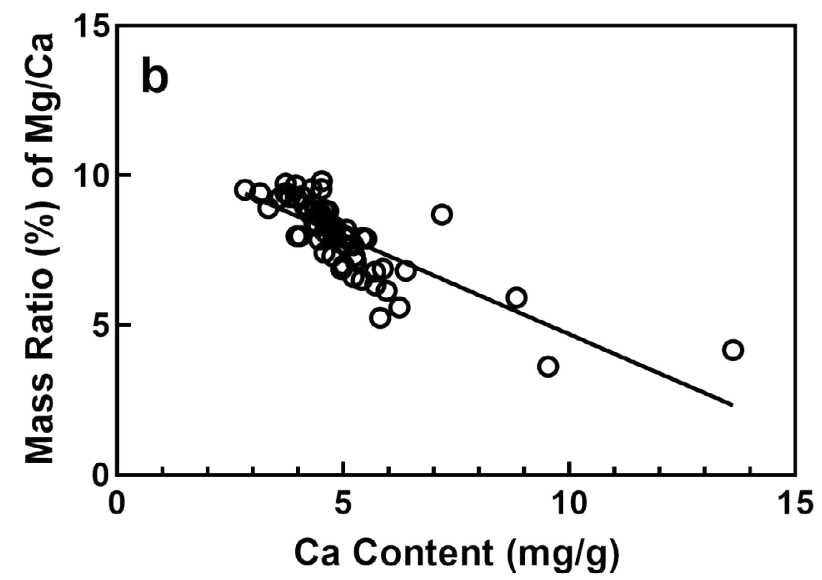

Figure 5: Changes of mass ratios of $\mathrm{Ca} / \mathrm{P}(\mathrm{a})$ and $\mathrm{Mg} / \mathrm{Ca}(\mathrm{b})$ in the FSBs. The mass ratios of $\mathrm{Ca} / \mathrm{P}$ and $\mathrm{Mg} / \mathrm{Ca}$ are plotted against the $\mathrm{Ca}$ content.

average mass ratio $(\mathrm{mg} / \mathrm{mg})$ of $\mathrm{Ca} / \mathrm{P}$ was high in the FSBs studied, being $6.75 \pm 3.93$.

Regarding the mass ratio of $\mathrm{Mg} / \mathrm{Ca}$, the correlation coefficient was estimated to be $-0.783(p<0.0001)$ between the mass ratio of $\mathrm{Mg} / \mathrm{Ca}$ and $\mathrm{Ca}$ content (Figure $5 b)$. The mass ratio of $\mathrm{Mg} / \mathrm{Ca}$ decreased significantly and gradually in the FSBs with $\mathrm{Ca}$ increase. The average mass ratio (\%) of $\mathrm{Mg} / \mathrm{Ca}$ was moderate in the FSBs studied, being $7.95 \pm 1.31 \%$.

\section{Discussion}

There are a few reports [4-6] on calcification of the FSB. Wasilewski et al. [4] investigated the LAD including the FSB in 309 patients with the mean age of 59.9 years by multi-slice computed tomography examination and revealed that calcification was most frequently located in the LAD in proximity to the origin of the FSB, but it was not located in the FSB. Wasilewski et al. [4] proposed that the septal branches generated disturbed flow in the LAD and posterior descending artery in a similar fashion to the myocardial bridge (myocardial bridge effect). Balghith et al. [5] investigated plaque distribution in the LAD by intravascular ultrasound in 50 patients with minimally obstructive coronary artery disease ( $<50 \%$ angiographic diameter stenosis) and re- 
vealed that in the LAD segment adjacent to the origin of the FSB, the mean atheroma area and the mean intimal thickness were substantially greater on the septal side than on the antiseptal side.

To examine age-related changes of the arteries supplying the conduction system of the heart, Velican et al. [6] investigated histological changes of the FSB, SAN artery, AVN artery, and posterior descending artery in the subjects of 6 to 55 years old. They reported that in apparently healthy persons, the incidence of intimal thickening in the FSB increased progressively from $9 \%$ at 21 25 years of age to $34 \%$ at $51-55$ years of age. However, they did not observe calcification in the tunica intima.

Vascular calcification is a hallmark of atherosclerosis. On calcification, deposition of calcium orthophosphate first occurs in the artery. Thereafter, it progresses to amorphous calcium phosphate and then to calcium phosphate crystalline structures such as hydroxyapatite [13]. Calcification occurs in most, but not all, arteries in old age [14].

To elucidate the manner of element accumulation in the arteries with aging, the authors $[8,9,15]$ investigated age-related changes of elements in the arteries and found that when calcification occurred in the arteries, a significant accumulation of $\mathrm{Ca}, \mathrm{P}$, and $\mathrm{Mg}$ occurred simultaneously in the arteries and both the $\mathrm{Ca}$ and $\mathrm{P}$ contents were well correlated with the $\mathrm{Mg}$ content. In addition, the mass ratio of $\mathrm{Ca} / \mathrm{P}$ was constant independently of $\mathrm{Ca}$ content, and the mass ratio of $\mathrm{Mg} / \mathrm{Ca}$ was low [16]. In the FSBs studied in the present study, the following results were obtained: Although the $\mathrm{P}$ content increased significantly with aging, the $\mathrm{Ca}$ and $\mathrm{Mg}$ contents did not increase with aging. No significant direct correlations were found among the $\mathrm{Ca}, \mathrm{P}$, and $\mathrm{Mg}$ contents, except for an extremely significant direct correlation between $\mathrm{Ca}$ and $\mathrm{Mg}$ contents. The mass ratio of $\mathrm{Ca} / \mathrm{P}$ increased significantly and progressively with $\mathrm{Ca}$ increase, being not constant. The average mass ratio of $\mathrm{Mg} / \mathrm{Ca}$ was moderate, being $7.95 \pm 1.31 \%$. Therefore, it was suggested that calcification scarcely occurred in the FSBs in old age. The present result is compatible with the finding by Wasilewski et al. [4].

The present study revealed that the average content of $P$ was very low in the FSBs studied. The authors [17] previously investigated the $\mathrm{Ca}, \mathrm{P}, \mathrm{S}$, and $\mathrm{Mg}$ contents in 19 kinds of Japanese arteries and found that the average contents of $P$ were very low in both the internal thoracic and the radial arteries, being $0.83 \pm 0.25 \mathrm{mg} / \mathrm{g}$ in the internal thoracic arteries and $0.85 \pm 0.66 \mathrm{mg} / \mathrm{g}$ in the radial arteries. These arteries are widely used for coronary artery bypass grafting $[18,19]$. It is recognized that atherosclerosis scarcely occurs in the internal thoracic artery in old age and occurs rarely in the radial artery [20]. Recently, the authors investigated age-related changes of ele- ments in the SAN artery [21], AVN artery [22], and the posterior intercostal artery [23], and found that the average contents of $P$ were very low in the three arteries. All the internal thoracic artery, radial artery, SAN artery, AVN artery, posterior intercostal artery, and FSB are characterized by a very low average content of $P$.

In the absence of calcification, the P content of tissue is mostly determined by the nucleic acid content (DNA and RNA) and the phospholipid content of tissue. Nucleic acids in the cell nucleus and the cytosol and phospholipids in the cell membrane are indicators of metabolically active cells [24]. Taking these into consideration, it is reasonable to presume that the $\mathrm{P}$ content in the artery indicates the active cell density, namely, the number of active cells per volume. Therefore, it is thought that the active cell density of the FSB increases slightly with aging.

There are two reports $[6,25]$ on the characteristic of the intimal thickening in the coronary arteries. Velican et al. [6] reported that in the arteries supplying the conduction system of the heart, intimal thickening was composed of smooth muscle cells, elastin, and proteoglycans, and that the incidence of intimal thickening in the FSB increased progressively with aging. Likewise, Nakashima et al. [25] reported that major components of intimal thickening in the coronary arteries were smooth muscle cells, elastin, and proteoglycans. The present study revealed that the $\mathrm{S}$ content increased significantly in the FSBs with aging. The $S$ content in the artery is mainly contained in the smooth muscle cell, collagen, and elastin [26]. According to the findings by Velican et al. [6] and Nakashima et al. [25], it is speculated that smooth muscle cells, elastin, and proteoglycans may increase mainly in the tunica intima of the FSB with aging.

\section{References}

1. Montenegro MR, Eggen DA (1968) Topography of atherosclerosis in the coronary arteries. Lab Invest 18: 586-593.

2. Azuma $C$, Tohno S, Mahakkanukrauh $P$, Tohno $Y$, Satoh $\mathrm{H}$, et al. (2003) Different accumulation of elements in the rami of the coronary arteries of Thai. Biol Trace Elem Res 95: 211-218.

3. Tohno $Y$, Tohno S, Mahakkanukrauh P, Minami T, Sinthubua A, et al. (2012) Accumulation of calcium and phosphorus in the coronary arteries of Thai subjects. Biol Trace Elem Res 145: 275-282.

4. Wasilewski J, Roleder M, Niedziela J, Nowakowski A, Osadnik T, et al. (2015) The role of septal perforators and "myocardial bridging effect" in atherosclerotic plaque distribution in the coronary artery disease. Pol J Radiol 80: 195-201.

5. Balghith MA, Schoenhagen P, Foody JM, lyisoy A, Crowe TD, et al. (2003) Atherosclerotic plaque distribution in the left anterior descending coronary artery as assessed by intravascular ultrasound. Am J Cardiol 91: 443-445.

6. Velican D, Serban-Piriu G, Petrescu C, Velican C (1989) 
Prevalence of thick intimas and of obstructive lesions in the vessels supplying the conduction system of the heart. Med Interne 27: 197-208.

7. Tohno $\mathrm{Y}$, Tohno S, Minami T, Ichii M, Okazaki Y, et al (1996) Age-related change of mineral content in the human thoracic aorta and in the human cerebral artery. Biol Trace Elem Res 54: 23-31.

8. Tohno S, Tohno Y, Minami T, Moriwake Y, Azuma C, et al (2002) Elements of calcified sites in human thoracic aorta. Biol Trace Elem Res 86: 23-30.

9. Tohno Y, Tohno S, Moriwake Y, Azuma C, Ohnishi Y, et al. (2001) Accumulation of calcium and phosphorus accompanied by increase of magnesium and decrease of sulfur in human arteries. Biol Trace Elem Res 82: 9-19.

10. Little PJ, Bhattacharya R, Moreyra AE, Korichneva IL (2010) Zinc and cardiovascular disease. Nutrition 26: 1050-1057.

11. Kraml P (2017) The role of iron in the pathogenesis of atherosclerosis. Physiol Res 66: S55-S67.

12. Tohno $Y$, Tohno $S$, Minami T, Utsumi M, Moriwake $Y$, et al. (1998) Age-related changes of mineral contents in the human aorta and internal thoracic artery. Biol Trace Elem Res 61: 219-226.

13. Nakahara T, Dweck MR, Narula N, Pisapia D, Narula J, et al. (2017) Coronary artery calcification: from mechanism to molecular imaging. JACC Cardiovasc Imaging 10: 582-593.

14. Ohnishi Y, Tohno S, Mahakkanukrauh P, Tohno Y, Vaidhayakarn P, et al. (2003) Accumulation of elements in the arteries and cardiac valves of Thai with aging. Biol Trace Elem Res 96: 71-92.

15. Tohno S, Tohno Y, Moriwake Y, Azuma C, Ohnishi Y, et al. (2001) Quantitative changes of calcium, phosphorus, and magnesium in common iliac arteries with aging. Biol Trace Elem Res 84: 57-66.

16. Bigi A, Compostella L, Fichera AM, Foresti E, Gazzano M, et al. (1988) Structural and chemical characterization of inorganic deposits in calcified human mitral valve. J Inorg Biochem 34: 75-82.
17. Tohno Y, Tohno S, Moriwake Y, Azuma C, Ohnishi Y, et al. (2001) Simultaneous accumulation of calcium, phosphorus, and magnesium in various human arteries. Biol Trace Elem Res 82: 21-28.

18. Sajja LR, Mannam G (2015) Internal thoracic artery: anatomical and biological characteristics revisited. Asian Cardiovasc Thorac Ann 23: 88-99.

19. Baikoussis N, Papakonstantinou NA, Apostolakis E (2014) Radial artery as graft for coronary artery bypass surgery: advantages and disadvantages for its usage focused on structural and biological characteristics. J Cardiol 63: 321328.

20. Kaufer E, Factor SM, Frame R, Brodman RF (1997) Pathology of the radial and internal thoracic arteries used as coronary artery bypass grafts. Ann Thorac Surg 63: 1118-1122.

21. Tohno $Y$, Tohno S, Quiggins R, Minami T, Mahakkanukrauh $P$ (2018) Scarce occurrence of calcification in human sinoatrial nodal arteries in old age. Biol Trace Elem Res 184: 24-32.

22. Tohno $Y$, Tohno S, Minami T, Mahakkanukrauh $P$, Phasukdee N (2018) Calcification scarcely occurs in human atrioventricular nodal arteries in old age. Ann Clin Anat 1: 1002.

23. Tohno $Y$, Tohno S, Minami T, Mahakkanukrauh P, Phasukdee N (2018) Age-related changes of elements in human posterior intercostal arteries and their observation by scanning electron microscopy. Geront Geriat Res 1: 115.

24. Oster O, Dahm M, Oelert H, Prellwitz W (1989) Concentrations of some trace elements ( $\mathrm{Se}, \mathrm{Zn}, \mathrm{Cu}, \mathrm{Fe}, \mathrm{Mg}, \mathrm{K}$ ) in blood and heart tissue of patients with coronary heart disease. Clin Chem 35: 851-856.

25. Nakashima Y, Chen YX, Kinukawa N, Sueishi K (2002) Distributions of diffuse intimal thickening in human arteries: Preferential expression in atherosclerosis-prone arteries from an early age. Virchows Arch 441: 279-288.

26. Looker T, Berry CL (1972) The growth and development of the rat aorta. II. Changes in nucleic acid and scleroprotein content. J Anat 113: 17-34. 